\title{
PENYESUAIAN DIRI TERHADAP FENOMENA GEGAR BUDAYA DI LINGKUNGAN KERJA
}

\author{
Ellya Pratiwi $^{{ }^{*}}$, dan Yanti Oktavianti Susanto ${ }^{2}$ \\ ${ }^{1,2}$ Institut Manajemen Wiyata Indonesia, Jawa Barat \\ *pratiwiellya@gmail.com
}

\begin{abstract}
The phenomenon of cultural shock in the work environment is an obstacle for immigrant employees both in their working performance and interpersonal communication in work environment. Therefore, adjustments are needed in order to adapt and communicate effectively. This research aims to determine the form of cultural shock in the work environment experienced by informants and how their efforts to adapt themselves to the culture shock phenomenon. Based on Lysgaard's $U$-curve model, the adjustment stage for a culture shock consists of the honeymoon, crisis, recovery and adjustment stages. This research used qualitative methods, with a phenomenological approach. The research found that there were two categories of cultural shock forms experienced by the informants. First, cultural shock on environmental differences, consisting of language, food, and weather. Second, cultural shocks in social life which consist of discriminatory attitudes due to ethnic and cultural differences, stereotypes, and discomfort with the communication climate in the company. Adaptation efforts were made, namely increasing intense interaction, learning Sundanese, understanding the character and habits of local employees, and participating in activities outside the company. The results of these adjustments depend on the intercultural communication competence and the character of each individual.
\end{abstract}

Keywords: culture shock, phenomenology, self-adjustement, intercultural communication.

\begin{abstract}
Abstrak
Fenomena gegar budaya di lingkungan kerja merupakan hambatan bagi karyawan dari kalangan pendatang baik bagi kinerjanya maupun komunikasi interpersonal di lingkungan kerja. Oleh karena itu, diperlukan upaya penyesuaian diri agar bisa beradaptasi dan berkomunikasi secara efektif. Penelitian ini dimaksudkan untuk mengetahui bentuk gegar budaya di lingkungan kerja yang dialami oleh para informan dan bagaimana upaya penyesuaian diri mereka terhadap fenomena culture shock tersebut. Berdasarkan model $U$-curve dari Lysgaard, tahap penyesuaian gegar budaya terdiri dari tahap kegembiraan, krisis, pemulihan, dan penyesuaian. Penelitian ini menggunakan metode kualitatif, dengan pendekatan fenomenologi. Hasil penelitian menemukan bahwa terdapat dua kategori bentuk gegar budaya yang dialami para informan. Pertama, gegar budaya pada perbedaan lingkungan, terdiri dari bahasa, makanan, dan cuaca. Kedua, gegar budaya pada kehidupan sosial yang terdiri dari sikap diskriminatif karena perbedaan suku dan budaya, stereotipe, dan ketidaknyamanan terhadap iklim komunikasi di perusahaan. Upaya adaptasi yang dilakukan yaitu meningkatkan interaksi secara intens, mempelajari bahasa Sunda, memahami karakter dan kebiasaan karyawan lokal, dan berpartisipasi dalam kegiatan di luar perusahaan. Hasil dari penyesuaian diri tersebut tergantung pada kompetensi komunikasi antarbudaya dan karakter masing-masing individu.
\end{abstract}

Kata kunci: gegar budaya, fenomenologi, penyesuaian diri, komunikasi antarbudaya.

\section{PENDAHULUAN}

Dinamika perekonomian di Indonesia seiring laju pertumbuhan teknologinya mendorong para tenaga kerja untuk mampu meningkatkan produktivitas dan performa kerja agar dapat bertahan dalam persaingan di dunia kerja. Berdasarkan Laporan Perekonomian Indonesia (LPI) tahun 2019 oleh Bank Indonesia menyatakan di tengah kinerja sektor eksternal yang kurang menguntungkan, permintaan domestik tetap kuat sehingga menopang pertumbuhan ekonomi Indonesia 
2019 tetap baik yakni 5,02\% (Indonesia, 2020). Di samping peningkatan keterampilan teknis pekerja, menurut laporan Robert Walters Indonesia, industri juga mempertimbangkan bagaimana kemampuan pekerja dalam beradaptasi, mengelola stakeholder, menjalin business partnership, dan kemampuan belajar (Setyaningrum, 2019). Keterampilan tersebut berkenaan dengan proses komunikasi, khususnya kompetensi pekerja dalam berkomunikasi di lingkungan kerja. Hal itu menunjukkan perlunya pekerja untuk meningkatkan kompetensi komunikasi, salah satunya adaptasi atau penyesuaian diri dengan lingkungan kerja.

Proses penyesuaian diri menjadi salah satu tantangan bagi para karyawan terutama bagi mereka yang berasal dari luar lingkungan sosial budaya yang berbeda dari daerah tempat mereka bekerja. Para karyawan membutuhkan upaya penyesuaian diri tersebut karena adanya potensi gegar budaya atau culture shock yang dapat dialami. Culture shock dalam kajian sosial disebut sebagai respon yang mendalam dan negatif dari depresi, frustasi, dan disorientasi yang dialami oleh individuindividu yang hidup dalam suatu lingkungan budaya yang baru (Dayaksini, 2012).

Ragam reaksi seperti rasa cemas saat seseorang memasuki lingkungan baru dengan budaya yang berbeda merupakan hal normal. Namun, perlu adanya upaya untuk menyesuaikan diri dengan lingkungan yang baru agar individu dapat melalui proses komunikasi secara efektif. Gegar budaya dapat dialami oleh siapapun di berbagai lingkungan masyarakat. Tidak terkecuali dengan pengalaman gegar budaya di lingkungan kerja. Situasi komunikasi pada lingkungan kerja begitu dinamis dan kompleks. Hal itu karena proses interaksi tidak hanya terjadi dalam bentuk komunikasi secara profesional, namun juga melibatkan bentuk komunikasi interpersonal dan hubungan antar elemen industri secara personal. Dengan demikian, gegar budaya di lingkungan kerja bukan hanya persoalan menyangkut kecemasan pribadi, namun juga berpotensi menjadi gangguan bagi performa kinerja individu yang mengalaminya.

Penelitian ini mengamati fenomena culture shock pada para karyawan asal luar Jawa Barat di PT Pratama Abadi Industri. Perusahaan tersebut merupakan industri manufaktur sepatu merk Nike yang bertempat di Sukabumi, Jawa Barat. Para tenaga kerja di perusahaan penghasil produk Nike tersebut tidak hanya berasal dari Jawa Barat tapi juga dari berbagai wilayah di Indonesia. Berdasarkan hasil olah data peneliti, jumlah karyawan yang berasal dari luar Jawa Barat khususnya pada divisi Manufacturing Excellent (ME), yaitu Jawa Tengah dan Jawa Timur mendominasi dengan jumlah $60 \%$, disusul oleh sumatera $20 \%$, Sulawesi $10 \%$, Sumatera dan Maluku masing-masing 5\% (gambar1).

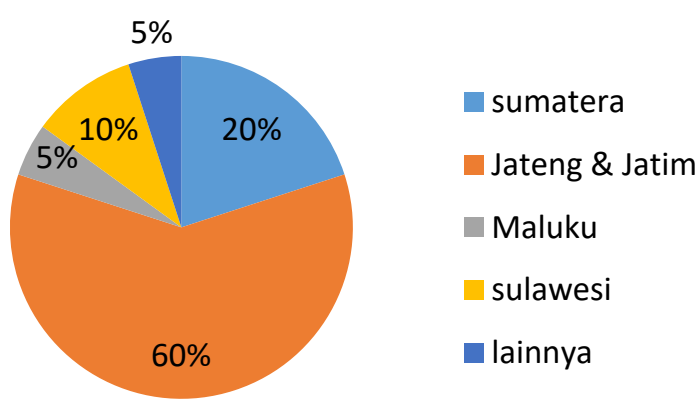

Gambar 1. Persentase jumlah karyawan yang berasal dari luar Jawa Barat di Divisi Manufacturing Excellent

Sumber: olah data pribadi, 2019

Perpindahan penduduk atau karyawan yang berasal dari daerah lain mengalami peningkatan karena didorong dengan penyerapan tenaga kerja yang terus meningkat pula. Selama empat periode 2015-2019, industri manufaktur terus menyerap tenaga kerja dalam negeri seiring adanya peningkatan investasi atau ekspansi. Ini menjadi salah satu efek berantai dari aktivitas industrialisasi yang sekaligus turut mendorong pertumbuhan ekonomi nasional (Kemenperin, 2019). Jumlah karyawan yang berasal dari luar Jawa Barat ini mau tak mau membuat semuanya harus bekerja berdampingan dan saling berhubungan satu 
sama lain di tempat kerja sehingga terjadi komunikasi antarbudaya.

Dalam keadaan demikian, seseorang segera dihadapkan kepada masalah-masalah yang ada dalam suatu situasi di mana suatu pesan disandi dalam suatu budaya dan harus disandi balik dalam budaya lain. Budaya bertanggung jawab atas seluruh perbendaharaan perilaku komunikatif dan makna yang di miliki setiap orang. Konsekuensinya, perbendaharaanperbendaharaan yang dimiliki dua orang yang berbeda budaya akan berbeda pula, yang dapat menimbulkan segala macam kesulitan. Ketika dua orang memiliki perbedaan yang besar terhadap latar belakang budayanya, maka hambatan yang muncul pada saat mereka melakukan kegiatan komunikasi juga akan semakin banyak.

Para karyawan asal luar Jawa Barat dalam prosesnya perlu menyesuaikan diri dengan lingkungan sosial dan budaya yang baru bagi mereka karena interaksi antar etnik tidak dapat dihindari. Saat seseorang melakukan komunikasi dengan orang lain yang berbeda budaya, maka orang tersebut akan dihadapkan dengan kenyataan di mana terdapat perbedaan bahasa, aturan-aturan, dan norma-norma yang membedakan antara orang tersebut dengan orang lain.

Jawa Barat merupakan provinsi yang sangat kental akan budaya Sunda. Karakteristik identitas etnik Sunda dikenal dengan sopan santun, someah (ramah), solider, mudah bergaul, dan agamis (Rahman, Sarbini, Tarsono, Fitriah, \& Mulyana, 2018). Ada pula stereotipe yang melekat pada masyarakat Sunda terutama dalam hal etos kerja yaitu entitas masyarakat Sunda dipandang tidak suka bekerja keras atau cenderung malas. Stereotipe itu salah satunya muncul dari folklor "Si Kabayan" (Rustandi \& Anggradinata, 2019). Budaya yang menjadi ciri khas masyarakat Sunda tidak hanya hal-hal yang berkaitan dengan sifat atau wataknya saja, tapi juga dari makanan. Kebiasaan orang Sunda mengonsumsi lalapan (sayuran mentah) juga merupakan budaya, tradisi, dan karakter masyarakat Sunda (Hendariningrum, 2018).

Budaya berkenaan dengan cara manusia hidup. Manusia belajar berpikir, merasa, mempercayai, dan mengusahakan apa yang patut menurut budayanya. Oleh karena itu, bahasa, persahabatan, kebiasaan makan, praktik komunikasi, tindakan-tindakan sosial, kegiatan ekonomi, politik dan teknologi, semua itu terbentuk berdasarkan pola pola budaya (Sihabudin, 2013). Hal inilah yang menyebabkan masyarakat memiliki caranya masing-masing dalam hal apapun di setiap aspek kehidupannya. Apa yang mereka lakukan, bagaimana mereka bertindak, merupakan respon terhadap fungsi-fungsi budayanya. Dalam penelitian ini, karyawan yang berasal dari luar Jawa Barat memiliki ciri khas budaya masing-masing. Ketika mereka pindah merantau ke Sukabumi-Jawa Barat maka perbedaan tersebut semakin signifikan.

Berbagai perbedaan kultur tersebut dapat berpotensi memicu gejala gegar budaya bagi para karyawan asal luar Jawa Barat, terutama saat awal-awal mereka tinggal di Sukabumi dan bekerja di PT Pratama Abadi Industri. Perbedaan-perbedaan kultur yang dialami oleh karyawan di tempat kerja dapat menimbulkan ketidaknyamanan dan akan memunculkan berbagai reaksi yang akan menghambat kesejahteraan psikologis individu untuk berfungsi optimal dalam kehidupan sehariharinya. Hal itu menarik untuk diamati dan diteliti lebih jauh guna mendapatkan suatu temuan sosial yang bermanfaat. Penelitian ini bertujuan untuk mengamati bentuk gegar budaya di lingkungan kerja yang dialami oleh para informan dan bagaimana upaya penyesuaian diri mereka terhadap fenomena gegar budaya tersebut.

\section{METODOLOGI}

Penelitian ini merupakan penelitian kualitatif deskriptif dengan menggunakan metode fenomenologi dan paradigma konstruktivisme. Fenomenologi termasuk ke dalam metode penelitian yang bersifat subjektif atau interpretif (Mulyana, 2018). Metode 
tersebut sesuai dengan tujuan penelitian ini yang berupaya untuk memperoleh gambaran persepsi dan interpretasi individu secara subjektif tentang pengalamannya dan mengamati sebuah kesadaran diri dari pengalaman yaitu keadaan yang memberikan sudut pandang pengalaman dari orang pertama.

Pengumpulan data diperoleh dari sumber data primer dan sekuder. Data primer diperoleh melalui wawancara mendalam dan observasi terhadap lima informan dengan karakteristik informan berasal dari luar Jawa Barat dan sudah bekerja di PT Pratama Industri minimal satu tahun. Kelima informan tersebut di antaranya Titin Agustina (karyawan asal Jawa Tengah), Karina Apriyanti (karyawan asal Jawa Timur), Fernando Binsar Napitulu (karyawan asal Sumatera Utara), Alfi Akbar (karyawan asal Sumatera Barat), dan Yohanna Sumampow (karyawan asal Sulawesi Utara). Pengumpulan data juga ditunjang dengan metode dokumentasi baik berupa pencatatan pada hasil pengamatan maupun data sekunder dari berbagai literatur yang relevan.

Pada tahapan analisis data, peneliti melakukan pembacaan secara berulang terhadap data yang telah diperoleh untuk kemudian dilakukan reduksi data yaitu proses pemilihan, pemusatan perhatian, dan identifikasi secara spesifik terhadap data-data yang penting, menarik, dan relevan dari para informan. Reduksi data bertujuan untuk memberi gambaran dan mempertajam hasil dari pengamatan yang sekaligus untuk mempermudah kembali pencarian data yang diperoleh. Selanjutnya, data disajikan ke dalam kesatuan bentuk data yang sederhana, selektif, logis, dan sistematis sehingga mudah dipahami. Pada tahap akhir, peneliti melakukan penarikan kesimpulan melalui upaya interpretasi dengan mengacu pada teori dan konsep yang digunakan.

\section{HASIL DAN PEMBAHASAN}

Komunikasi antarbudaya pada dasarnya mampu menghasilkan keselarasan dan kebersamaan di tengah perbedaan budaya terutama bagi masyarakat Indonesia yang multikultural. Komunikasi antarbudaya dapat didefinisikan sebagai proses pertukaran pikiran dan makna di antara orang-orang yang berasal dari budaya yang berbeda. Komunikasi antarbudaya juga memiliki manfaat sebagai salah satu hal yang dapat digunakan untuk memahami sisi perbedaan antarbudaya (Karmilah \& Sobarudin, 2019). Namun, pada prosesnya ketika seseorang memasuki lingkungan baru dengan latar belakang budaya yang berbeda, tidak jarang seseorang mengalami hambatan yang diakibatkan perbedaan budaya tersebut.

Salah satunya adalah fenomena culture shock atau gegar budaya. Culture shock merupakan istilah untuk menggambarkan proses ketika seseorang merasakan frustasi atau perasaan tidak nyaman terhadap wilayah baru oleh orang tersebut, yang dapat disebabkan karena perbedaan antara dua orang atau dua kebudayaan. Gegar budaya biasanya dapat dialami oleh seseorang yang baru pindah ke lingkungan baru, sehingga orang tersebut harus beradaptasi dengan lingkungan barunya tersebut (Nunez, Mahdi, \& Popma, 2017).

Pada dasarnya, gegar budaya muncul karena benturan persepsi yang diakibatkan penggunaan persepsi berdasarkan faktor-faktor internal (nilai-nilai budaya) yang telah dipelajari orang bersangkutan dalam lingkungan baru yang dinilai budayanya berbeda dan belum dipahaminya (Rakhmat \& Mulyana, 2006). Benturan-benturan persepsi itu kemudian menimbulkan konflik dalam diri individu serta menyebabkan individu merasa tertekan dan stress. Efek inilah yang kemudian disebut sebagai gegar budaya (culture shock). Ketika orang-orang yang berasal dari latar belakang budaya berbeda saling berkomunikasi, penafsiran keliru atas sandi merupakan pengalaman yang lazim. Komunikasi antar budaya dapat terjadi dalam konteks komunikasi manapun, mulai dari komunikasi dua orang yang intim hingga ke komunikasi organisasional dan komunikasi massa.

Ketika gejala gegar budaya dialami seseorang, terdapat reaksi yang muncul baik 
secara psikologis maupun reaksi pada fisik. Reaksi tersebut dapat dialami secara berbeda pada setiap masing-masing individu. Saat menghadapi beberapa efek dari gegar budaya, tidak jarang orang mengalami rasa disorientasi, perasaan ditolak, rindu kampung halaman, penarikan diri, iritasi, serta kelelahan fisik dan mental (Samovar, Porter, McDaniel, \& Roy, 2012). Gegar budaya juga dapat menyebabkan reaksi pada fisik seperti sakit perut dan kepala, serta perubahan pada pola tidur dan pola makan (Aldino, 2020). Sebagaimana hasil riset sebelumnya, individu yang mengalami kontak dengan budaya lain merasakan ketidaknyamanan psikis dan fisik. Hasil peneltian ini menunjukkan bahwa permasalahan yang timbul akibat culture shock tidak hanya bersifat emosional namun juga dari segi fisik yang dapat menyebabkan seseorang mengalami gangguan fisik dan sakit (Suyandari, 2012).

Banyak aspek budaya yang turut menentukkan perilaku komunikatif individu dengan individu lainnya. Unsur-unsur sosiobudaya ini tersebar dan meliputi banyak kegiatan sosial manusia. Beberapa unsur sosiobudaya yang berhubungan dengan komunikasi diantaranya bahasa, kata-kata, makna, nada suara, emosi, kontak fisik, dampak dan waktu secara kultural, tempat, hubungan-hubungan kelas sosial, persepsi, sistem kepercayaan, nilai, dan sikap yang berlaku pada suatu masyarakat budaya tertentu (Sihabudin, 2013)

Fenomena culture shock berlangsung dalam empat tahapan yang dialami oleh individu (Oberg, 1960). Pertama, tahap bulan madu (honeymoon) yaitu masa di mana orang merasa tertarik dan senang dengan lingkunan dan budaya barunya. Kedua, masa kesedihan (crisis) yaitu munculnya masalah dalam diri seperti frustasi akibat perbedaan budaya dan tatanan lingkungan. Fase ini merupakan masa krisis karena individu mengalami kejutan nyata dari budaya baru. Ketiga, masa pemulihan (recovery) yaitu masa di mana seseorang mulai memahami budaya barunya dengan mempelajari hal-hal terkait budaya tersebut seperti bahasa. Secara bertahap, orang mulai menyesuaikan diri untuk menanggulangi permasalahannya dengan budaya baru hingga kecemasannya mereda. Keempat, masa penyesuaian (adjustment) yaitu tahap di mana orang mulai menikmati budaya baru sebagai pengalaman baru yang menyenangkan. Proses penyesuaian ini membuat orang mampu beradaptasi dengan budaya barunya secara lebih baik (Devito, 2015).

\section{Teori Penyesuaian Diri Model $\boldsymbol{U}$-Curve}

Kemampuan setiap orang berbeda-beda dalam beradaptasi dan menyesuaikan diri dengan lingkungan sosial dan budaya yang baru. Upaya penyesuaian diri tersebut diperlukan agar para pendatang di lingkungan baru dapat membentuk pola komunikasi yang efektif dengan orang-orang di sekitarnya. Orang yang memasuki lingkungan budaya baru membutuhkan waktu untuk beradaptasi dengan melalui proses yang bertahap hingga akhirnya ia merasa nyaman dengan budaya barunya. Secara teoritis, tahapan-tahapan tersebut diperkenalkan oleh Lysgaard yang menggambarkannya ke dalam model $U$-curve atau $U$-curve theory of adjustment (Lysgaard, 1955).

Gagasan utama dari teori ini yaitu bahwa orang akan menjalani fase-fase yang dapat diprediksi dalam beradaptasi dengan situasi budaya yang baru (Rahardjo, Dwiningtyas, \& Pradekso, 2018). Fase-fase tersebut digambarkan ke dalam sebuah kurva berbentuk $U$ yang secara spesifik kurva $U$ ini melewati empat tingkatan yaitu honeymoon, crisis, recovery, dan adjustment (gambar 2).

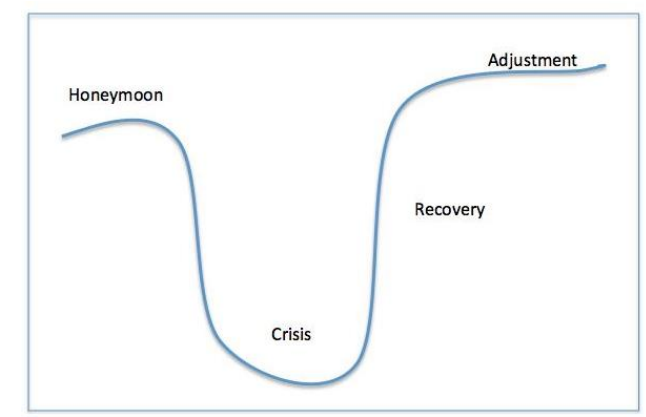

Gambar 2. U-Curve Model

Sumber: International Office Berkeley Education 
Tahap penyesuaian diawali dengan perasaan optimis dan kegembiraan, namun kemudian muncul permasalahan seperti frustasi, ketegangan dam kecemasan hingga individu tidak dapat berkomunikasi secara efektif dengan lingkungan barunya (Utami, 2015). Orang yang berusaha untuk menysuaikan diri, pada tahap selanjutnya mereka akan termotivasi untuk melakukan upaya-upaya penyesuaian diri pada fase pemulihan (recovery), hingga akhirnya mereka mampu meredakan gegar budaya dan secara efektif mampu berkomunikasi dan beradaptasi dengan lingkungan barunya.

Secara spesifik, pada tahap awal yaitu fase honeymoon (bulan madu) berada pada bagian kiri atas dari Kurva U. Tahap ini menunjukkan kegembiraan dan ketertarikan individu saat akan memasuki lingkungan baru. Pada umumnya, individu yang hendak merantau memiliki ekspektasi tinggi terhadap lingkungan barunya. Ekspektasi tersebut cenderung menghadirkan rasa bahagia karena individu tersebut memiliki euforia yang menggebu-gebu (Fadillah, 2020).

Pada tahap selanjutnya yaitu fase crisis menunjukkan rasa terkejut individu terhadap lingkungan barunya hingga muncul kekecewaan dan ketidakpuasan akibat ekspektasi di awal tidak sesuai dengan apa yang ia alami (Fadillah, 2020). Sebagai akibatnya, orang menjadi bingung dan tercengang dengan sekitarnya hingga menyebabkan frustasi dan reaksi-reaksi emosional lainnya. Ini merupakan fase culture shock yang dirasakan para pendatang. Pada lingkungan kerja, gegar budaya ini akan menghambat orang dalam pekerjaannya karena pada titik tertentu orang menjadi tidak kompeten akibat gegar budaya itu sendiri.

Tahap ketiga yaitu fase recovery atau pemulihan yang ditandai dengan munculnya motivasi pada diri individu untuk melakukan perubahan dan penyesuaian diri terhadap budaya baru. Terdapat peningkatan pengetahuan individu mengenai budaya di lingkungan baru yang ditempatinya. Secara bertahap, orang akan membuat penyesuaian dan perubahan dalam caranya menanggulangi budaya baru. Orang-orang dan peristiwa dalam lingkungan baru mulai dapat terprediksi dan tidak terlalu menekan (Devinta, Hidayah, \& Hendrastomo, 2015).

Tahap akhir yaitu adjustment atau penyesuaian yaitu pada puncak kanan $\mathrm{U}$ di dalam kurva. Pada tahap ini, orang telah mengerti elemen kunci dari budaya barunya yakni berupa nilai-nilai, adaptasi khusus, pola komunikasi, keyakinan, dan sebagainya. Orang juga mulai merasa nyaman dengan lingkungan barunya (Samovar, Porter, McDaniel, \& Roy, 2012). Tahap adjustment merupakan fase akhir di mana penyesuaian diri berhasil dilakukan meskipun mungkin tidak secara sempurna seseorang dapat mengadaptasi budaya barunya secara keseluruhan. Namun, gejala-gejala gegar budaya pada umumnya sebagian besar sudah bisa ditanggulangi.

Pengalaman gegar budaya, upaya adaptasi dan fase dalam penyesuaian diri tiap orang berbeda-beda. Begitu pula jangka waktu yang dilalui tiap orang berbeda-beda dalam melewati masa gegar budaya hingga berhasil beradaptasi di lingkungan barunya. Model $U$ curve ini bersifat simplisitik dan bertujuan untuk merepresentasikan tahapan-tahapan yang umumnya dilewati dan dirasakan ketika seseorang menempati lingkungan sosial dan budaya baru.

\section{Bentuk Gegar Budaya Pada Karyawan Asal Luar Jawa Barat}

Lima karyawan PT Pratama Industri Abadi sebagai informan penelitian berasal dari berbagai daerah di luar Jawa Barat, antara lain Alfi Akbar asal Bukittinggi-Sumatera Barat, Fernando Binsar Napitupulu asal BaligeSumatera Utara, Karina Apriyanti asal Nganjuk-Jawa Timur, Titin Agustina asal Temanggung-Jawa Tengah, dan Yohanna Sumampow asal Manado-Sulawesi Utara. Kelima informan tersebut memiliki latar belakang budaya yang berbeda, namun memiliki tujuan yang hampir sama saat memutuskan untuk bekerja di luar 
daerahnya/Sukabumi, yaitu untuk menambah pengalaman dan mendapatkan penghasilan.

Karyawan dari luar Jawa Barat sebelumnya memiliki faktor-faktor tertentu yang membuat mereka melakukan perantauan, sebagian besar diantaranya adalah untuk mencari pengalaman bekerja yang lebih luas dan memenuhi kebutuhan hidupnya secara mandiri. Merantau bukanlah hal yang mudah dikarenakan para karyawan yang berasal dari luar Jawa Barat diharuskan untuk hidup mandiri tanpa ada yang mendampingi, terlebih dengan jarak yang cukup jauh. Perpindahan para informan dari tempat tinggalnya masingmasing untuk bekerja di Sukabumi disertai dengan harapan dan ekspektasi mereka terhadap perusahaan serta lingkungan di Sukabumi. Para informan mengaku merasa sangat tertarik, senang sekaligus penasaran ketika hendak pindah ke Sukabumi. Terutama bagi mereka yang notabene sebagai fresh graduate saat itu, merasa bersemangat karena berhasil mendapatkan pekerjaan meskipun berada jauh dari tempat tinggal asal.

Tabel 1. Motivasi dan Kondisi Informan Pada Tahap Honeymoon

\begin{tabular}{lll}
\hline \multicolumn{1}{c}{ Informan } & $\begin{array}{c}\text { Faktor Pendorong Informan Tinggal di } \\
\text { Sukabumi }\end{array}$ & \multicolumn{1}{c}{$\begin{array}{c}\text { Tahap Honeymoon/Fase } \\
\text { Kegembiraan }\end{array}$} \\
\hline $\begin{array}{l}\text { Alfi Akbar } \\
\text { (Bukittinggi) }\end{array}$ & $\begin{array}{l}\text { Motivasi pengalaman bekerja sebagai } \\
\text { fresh graduate, kebutuhan ekonomi }\end{array}$ & $\begin{array}{l}\text { Berekspektasi adanya sesuatu baru } \\
\text { yang menyenangkan di lingkungan } \\
\text { baru }\end{array}$ \\
\hline $\begin{array}{l}\text { Fernando Binsar N N } \\
\text { (Balige) }\end{array}$ & $\begin{array}{l}\text { Kebutuhan ekonomi dan fasilitas yang } \\
\text { ditawarkan perusahaan }\end{array}$ & Merasa bersemangat dan bangga \\
\hline $\begin{array}{l}\text { Karina Apriyanti } \\
\text { (Nganjuk) }\end{array}$ & Kebutuhan ekonomi & Merasa terkejut dan sangat senang \\
\hline $\begin{array}{l}\text { Titin Agustina } \\
\text { (Temanggung) }\end{array}$ & $\begin{array}{l}\text { Keinginan untuk merantau dan kebutuhan } \\
\text { ekonomi }\end{array}$ & Senang dan bersemangat \\
\hline $\begin{array}{l}\text { Yohanna S } \\
\text { (Manado) }\end{array}$ & $\begin{array}{l}\text { Motivasi pengalaman bekerja sebagai } \\
\text { fresh graduate dan rasa penasaran dengan } \\
\text { lingkungan baru (Sukabumi) }\end{array}$ & $\begin{array}{l}\text { Merasa takut namun penasaran } \\
\text { dengan lingungkan baru }\end{array}$ \\
\hline
\end{tabular}

Sumber: olah data pribadi (2019)

Munculnya harapan dan ekspektasi tersebut menandakan para informan selaku pendatang berada pada fase honeymoon di mana belum muncul gejala gegar budaya melainkan rasa gembira dan harapan atau ekspektasi terhadap lingkungan barunya. Dapat disimpulkan pula bahwa para informan secara umum masih belum memiliki gambaran seperti apa kota atau tempat yang akan mereka tinggali sebelumnya, karakteristik masyarakatnya, kebudayaannya, dan sebagainya. Artinya, pengetahuan mereka mengenai budaya dan sosial kota Sukabumi baru terbentuk setelah mereka melakukan interaksi di lingkungan barunya tersebut. Menurut DeVito (2015), penting untuk mempelajari suatu budaya tertentu di mana orang akan terlibat dalam komunikasi di dalamnya sebagai persiapan untuk proses komunikasi antarbudaya. Ketika pengetahuan dan persiapan itu belum dimiliki individu, maka potensi terkena gejala gegar budaya menjadi lebih besar.

Dalam penelitian ini, pemahaman baru yang tercipta terjadi ketika seseorang sedang melakukan perantauan terbentuk dari interaksi atau hubungan yang dilakukan dengan orang lain. Hasil wawancara terhadap kelima informan menunjukkan bahwa mereka secara serentak mengalami gegar budaya saat awal berada di Sukabumi, terutama di lingkungan kerja sebagai tempat di mana mereka melakukan banyak interaksi dengan karyawan dari kalangan masyarakat lokal setiap harinya. Ini merupakan tahap krisis di mana para informan merasakan kekecewaan dan ketidakpuasan akibat ekspektasi di awal tidak sesuai dengan apa yang ia alami (Fadillah, 2020). 
Tabel 2. Bentuk Gegar Budaya Pada Tahap Krisis

\begin{tabular}{|c|c|c|c|}
\hline \multirow[t]{2}{*}{ Informan } & \multicolumn{2}{|c|}{ Tahap Krisis/Gegar Budaya } & \multirow[t]{2}{*}{ Reaksi } \\
\hline & Aspek Lingkungan & Aspek Kehidupan Sosial & \\
\hline $\begin{array}{l}\text { Alfi Akbar } \\
\text { (Bukittinggi) }\end{array}$ & $\begin{array}{l}\text { Perbedaan bahasa, } \\
\text { makanan, dan cuaca }\end{array}$ & $\begin{array}{l}\text { - Ketidakcocokan dengan karakter } \\
\text { karyawan lokal yang dinilai lebih } \\
\text { sensitif dan mudah marah. } \\
\text { - Ketidaksesuaian dalam } \\
\text { pemahamanan ketika berinteraksi } \\
\text { dengan karyawan lokal. } \\
\text { - Ekspektasi di awal tidak sesuai } \\
\text { dengan realita. }\end{array}$ & $\begin{array}{l}\text { - Tidak tertarik } \\
\text { untuk terlibat } \\
\text { dalam } \\
\text { percakapan. } \\
\text { - Kecewa. }\end{array}$ \\
\hline $\begin{array}{l}\text { Fernando } \\
\text { Binsar N } \\
\text { (Balige) }\end{array}$ & $\begin{array}{l}\text { Perbedaan bahasa, } \\
\text { makanan, dan cuaca. }\end{array}$ & $\begin{array}{l}\text { Ketidakcocokan dengan karakter } \\
\text { karyawan lokal yang dinilai } \\
\text { mudah tersinggung, marah, dan } \\
\text { cenderung malas dalam bekerja. } \\
\text { - Kesalahpahaman karena logat } \\
\text { Sumatera yang tegas/keras. }\end{array}$ & $\begin{array}{l}\text { - Sakit akibat } \\
\text { cuaca di minggu } \\
\text { awal bekerja. } \\
\text { - Merasa sedih dan } \\
\text { takut. }\end{array}$ \\
\hline $\begin{array}{l}\text { Karina } \\
\text { Apriyanti } \\
\text { (Nganjuk) }\end{array}$ & $\begin{array}{l}\text { Perbedaan bahasa, } \\
\text { makanan. }\end{array}$ & $\begin{array}{l}\text { - Ketidakcocokan dengan iklim } \\
\text { perusahaan karena kurang kuat } \\
\text { suasana kekeluargaannya } \\
\text { - Merasa tidak dianggap dan } \\
\text { menilai diri sebagai minoritas }\end{array}$ & $\begin{array}{l}\text { - Rasa ingin } \\
\text { kembali ke } \\
\text { kampung } \\
\text { halaman } \\
\text { (homesick). } \\
\text { - Sering menangis. }\end{array}$ \\
\hline $\begin{array}{l}\text { Titin Agustina } \\
\text { (Temanggung) }\end{array}$ & $\begin{array}{l}\text { Perbedaan bahasa, } \\
\text { makanan, dan cuaca. }\end{array}$ & $\begin{array}{l}\text { Ketidakcocokan dengan karakter } \\
\text { karyawan lokal yaitu kurang } \\
\text { tanggung jawab dan kurang } \\
\text { disiplin. } \\
\text { - Mengalami perlakuan } \\
\text { diskriminasi dari karyawan lokal } \\
\text { karena logat Jawa yang kental } \\
\text { dan perbedaan warna kulit. }\end{array}$ & $\begin{array}{l}\text { - Sakit perut, mual, } \\
\text { pusing, dan } \\
\text { berdebar ketika } \\
\text { berinteraksi } \\
\text { dengan para } \\
\text { karyawan lokal. } \\
\text { - Perasaan sedih } \\
\text { dan bingung, } \\
\text { kurang percaya } \\
\text { diri. }\end{array}$ \\
\hline $\begin{array}{l}\text { Yohanna S } \\
\text { (Manado) }\end{array}$ & $\begin{array}{l}\text { Perbedaan bahasa dan } \\
\text { cucaca. }\end{array}$ & $\begin{array}{l}\text { Ketidakcocokan dengan sikap } \\
\text { karyawan lokal yang dinilai terlalu } \\
\text { mencampuri ruang pribadi } \\
\text { (personal space) }\end{array}$ & $\begin{array}{l}\text { - Sakit akibat } \\
\text { cuaca. } \\
\text { - Rasa tidak } \\
\text { nyaman. }\end{array}$ \\
\hline
\end{tabular}

Sumber: olah data pribadi (2019)

Bentuk culture shock yang dialami para informan secara umum dapat dibagi menjadi dua kategori. Pertama, culture shock pada perbedaan lingkungan. Kedua, culture shock pada kehidupan sosial. Bentuk culture shock pada perbedaan lingkungan dirasakan oleh hampir seluruh informan terutama pada bahasa, makanan, dan cuaca. Perbedaan bahasa merupakan pemicu paling utama bagi mereka terhadap pengalaman gegar budaya para informan mengakui kesulitan perihal bahasa di mana karyawan lokal menggunakan bahasa Sunda sebagai bahasa ibu, hingga menghambat proses komunikasi di lingkungan kerja. Sebagaimana peranyataan Harper bahwa kurangnya keterampilan bahasa merupakan penghalang kuat untuk penyesuaian budaya dan komunikasi yang efektif, sedangkan kurangnya 
pengetahuan tentang cara berbicara kelompok tertentu akan mengurangi tingkat pemahaman mengenai masyarakat lokal (Samovar, Porter, McDaniel, \& Roy, 2012).

Kesalahpahaman tidak hanya terjadi pada informan, namun juga pada karyawan lokal. Logat bahasa Sunda yang cenderung halus dan mendayu berbeda dengan logat bahas Sumatera yang cenderung keras dan tegas. Sebagaimana yang dialami Fernando dan Alfi, karena logat Sumateranya yang khas, para karyawan lokal kerap kali menganggapnya marah ketika sedang berbicara. Hal tersebut menjadi salah satu penghambat bagi keduanya dalam berkomunikasi dengan sesama rekan karyawan di lingkungan kerja.

Perbedaan makanan juga menjadi kendala bagi para informan dalam beradaptasi. Perbedaan dari segi makanan, seperti komposisi makanan, takaran bumbu dan rempah, cara menyajikan, bahkan cara makan sering kali berbeda antara budaya yang satu dengan budaya yang lainnya. Perbedaan cita rasa yang kuat dapat mempengaruhi beberapa hal seperti masalah pencernaan hingga kehilangan nafsu makan. Masyarakat Sukabumi yang kental akan budaya Sunda sangat khas dengan lalapan sebagai makanan yang biasa dikonsumsi. Empat dari lima informan mengaku bahwa mereka tidak cocok dengan cita rasa makanan khas masyarakat lokal.

Di samping bahasa dan makanan, cuaca pun menjadi salah satu penyumbang gegar budaya lainnya. Sukabumi merupakan daerah dataran tinggi yang diapit oleh Gunung Gede dan Gunung Pangrango dengan suhu udara yang sejuk bahkan dingin terutama ketika memasuki puncak kemarau dimana suhu menjadi lebih dingin dan kering. Karyawan dari luar Jawa Barat yang notabene berasal dari dataran rendah harus berjuang untuk menyesuaikan diri dengan suhu tersebut bahkan ada juga yang jatuh sakit saat awal pindah dan bekerja.

Kategori kedua dari bentuk gegar budaya yang dialami informan yaitu terkait kehidupan sosial terutama di lingkungan kerja. Proses komunikasi dengan sesama karyawan lokal di perusahaan menghasilkan berbagai dinamika pengalaman gegar budaya bagi masing-masing informan. Hasil penelitian mengemukakan bentuk gegar budaya pada aspek kehidupan sosial informan di lingkungan kerja antara lain sikap diskriminatif karena perbedaan suku dan budaya, penilaian negatif oleh informan terhadap karyawan lokal berdasarkan pengalaman pribadi, dan ketidaknyamanan informan atas iklim komunikasi di perusahaan.

Bentuk sikap diskriminatif berupa pandangan dan stereotipe yang dilatari perbedaan suku dan budaya dialami oleh Titin. Sebagaimana penuturannya yang mengungkapkan bahwa suku Jawa dipandang sebelah mata. Hal itu ia ungkapkan karena logat Jawa yang kental ketika ia berbicara dan perbedaan warna kulit yang cenderung lebih gelap dibandingkan karyawan lokal pada umumnya. Dari beberapa informan sendiri menilai ada perbedaan karakter yang melekat pada masyarakat lokal di mana karakter tersebut mereka rasakan tidak sejalan dengan nilai-nilai yang mereka pegang. Alfi menilai karakter karyawan lokal lebih sensitif dan mudah marah. Hal itu juga disebabkan oleh perbedaan logat bahasa saat berinteraksi.

Adapun Fernando menilai karakter yang ia tidak sukai dari karyawan lokal yang berinteraksi dengan dirinya yaitu cenderung malas dan mudah tersinggung. Hal itu menurutnya bertolak belakang dengan prinsip pribadinya. Perbedaan prinsip tersebut menimbulkan ketidaknyamanan bagi informan sehingga menjadi hambatan dalam komunikasi terutama untuk urusan pekerjaan. Bagi informan lainnya yaitu Karina, bentuk keterkejutan terhadap perbedaan kultural terkait kehidupan sosial di lingkungan kerja yaitu sikap karyawan lokal cenderung melewati batasan ruang pribadi (personal space) individu. Hal itu ia bandingkan dengan karakter orang-orang di berbagai tempat yang sebelumnya ia tinggali. Pada budaya di tempat sebelumnya, tidak ada tekanan secara sosial untuk selalu berbagi hal-hal menyangkut kehidupan pribadi kepada orang lain. Karakter 
seperti demikian membuat ia mengalami gegar budaya di lingkungan kerjanya saat ini.

Secara keselurhan, reaksi dari gegar budaya pada para informan cukup beragam baik reaksi psikologis maupun secara fisik. Hal umum yang dirasakan informan pada fase gegar budaya yaitu rasa sedih hingga sering menangis, kurang percaya diri, takut, bingung, tidak nyaman, dan rasa ingin kembali ke kampung halaman. Reaksi terhadap fisik juga dialami oleh beberapa informan seperti mual, pusing, sakit perut, dan berdebar-debar saat berinteraksi dengan karyawan lokal di lingkungan kerja maupun disebabkan cuaca. Berbagai perbedaan kultural dan reaksi dari gejala gegar budaya membuat kelima informan melakukan interaksi dan penyesuaian terhadap lingkungan kerjanya. Secara bertahap, mereka membuat beberapa penyesuaian dan modifikasi untuk menaggulangi segala permasalahan terkait budaya baru.

\section{Upaya Penyesuaian Diri terhadap Gegar Budaya di Lingkungan Kerja}

Ketika mengalami gegar budaya, para informan tentu tidak ingin berlarut-larut dalam kekecewaan karena hal tersebut dapat menghambat keberlangsungan hidup mereka selama di tempat kerja. Oleh karena itu, mereka melakukan proses interaksi untuk menyesuaikan diri mereka dengan lingkungan baru. Dalam mengatasi gegar budaya, kelima informan memiliki cara dan pendekatan mereka sesuai dengan pengalamannya masing-masing.

Merujuk pada model $U$-curve, proses penyesuaian merupakan fase pemulihan atau tahap recovery yaitu adanya motivasi untuk menyesuaikan diri terhadap lingkungan budaya baru. Pada fase ini, para informan sudah mulai mengenali hal-hal terkait budaya barunya sehingga secara bertahap mereka melakukan penyesuaian terhadap lingkungannya dengan pendekatan masing-masing. Tujuannya adalah untuk meredakan gegar budaya, mendapatkan kenyamanan, dan mencapai komunikasi yang efektif dengan orang-orang di sekitar.

Kesadaran akan perlunya upaya penyesuaian diri tersebut bagi beberapa informan diakui terpacu karena adanya beberapa faktor. Pertama, tujuan pribadi, citacita, dan harapan sebagai motivasi untuk tetap bertahan di tengah perbedaan budaya. Kedua, adanya keinginan kuat untuk diterima di lingkungan kerja. Ketiga, peran orang-orang terdekat atau sahabat dan para relasi dalam proses penyesuaian diri.

Ada beragam cara yang dilakukan para informan untuk menyesuaikan diri pada tahap pemulihan (recovery). Berdasarkan hasil wawancara, upaya penyesuaian diri dilakukan dengan cara meningkatkan intensitas interaksi dengan karyawan lokal, mempelajari bahasa Sunda, mencoba memahami karakter dan kebiasaan para karyawan lokal, berpartisipasi dengan para karyawan lokal dalam kegiatan di luar perusahaan, dan berbaur dengan rekanrekan karyawan lokal. Secara keselurhan, upaya-upaya yang dilakukan para informan melibatkan pendekatan emosional dengan harapan agar bisa menjalin komunikasi yang baik dengan para karyawan lokal (tabel 3).

Tabel 3. Upaya Penyesuaian Diri pada Tahap Pemulihan (Recovery)

Informan Upaya Penyesuaian Diri Pada Tahap Pemulihan (Recovery)

\begin{tabular}{ll}
\hline $\begin{array}{l}\text { Alfi Akbar } \\
\text { (Bukittinggi) }\end{array}$ & $\begin{array}{l}\text { Tidak ada cara khusus untuk beradaptasi karena pribadi informan yang cuek } \\
\text { dan bersikap apa adanya. }\end{array}$ \\
\hline Fernando Binsar N & • Adanya keinginan kuat untuk diterima. \\
(Balige) & - Dukungan dari orang terdekat. \\
& - Belajar memahami karakter para karyawan lokal. \\
& • Berinterkasi secara intens dan berpartisipasi dalam kegiatan di luar kantor. \\
\hline Karina Apriyanti & - Berinteraksi secara intens. \\
(Nganjuk) & - Mempelajari bahasa Sunda. \\
\hline
\end{tabular}




\begin{tabular}{ll}
\hline Titin Agustina & - Menjadikan tujuan pribadi dan cita-cita sebagai motivasi untuk terus bertahan. \\
(Temanggung) & - Memperluas pertemanan dan mendapat dukungan dari sahabat. \\
\hline Yohanna S & - Berinteraksi secara intens. \\
(Manado) & - Bersilaturahmi di luar lingkungan kerja. \\
& - Mempelajari bahasa Sunda dan kebiasaan-kebiasaan karyawan lokal.
\end{tabular}

Sumber: olah data pribadi (2019)

Upaya-upaya penyesuaian diri tersebut menghasilkan pengaruh positif terhadap pemulihan gegar budaya para informan. Pada tahap ini terdapat perubahan yang terjadi pada para informan dibandingkan dengan kondisi sebelumnya di tahap krisis. Peningkatan kemampuan berbahasa Sunda menjadi perubahan signifikan yang dicapai para informan pada masa pemulihan (recovery). Upaya mempelajari bahasa budaya lokal merupakan langkah bagi pendatang yang mengalami gegar budaya agar bisa beradaptasi dengan orang-orang di lingkungan barunya (Samovar, Porter, McDaniel, \& Roy, 2012). Oleh karena itu, ketika para informan meningkatkan kemampuan bahasa Sunda, mereka dapat mulai beradaptasi dan berkomunikasi dengan orang-orang di sekitarnya secara lebih baik.

Berbeda dengan informan lainnya, Alfi mengaku tidak melakukan cara khusus untuk beradaptasi. Hal itu karena pada dasarnya ia adalah orang yang cuek karena itu ia hanya mengikuti arus dan alur komunikasi di lingkungan yang ada. Pada akhirnya, hal itu menghambatnya dalam beradaptasi. Sampai pada tahun pertama sejak ia bergabung di perusahaan, ia belum menemukan titik nyaman di lingkungan kerjanya. Ia juga tidak merasa ada perubahan. Dapat disimpulkan bahwa proses adaptasi Alfi tidak berlanjut pada fase selanjutnya yaitu tahap penyesuaian (adjustment), atau bahkan masih berada di transisi antara tahap krisis ke tahap pemulihan. Hal itu terjadi karena ekspektasi yang muncul pada tahap honeymoon tidak sejalan dengan realita yang ia hadapi dikarenakan banyak perbedaan budaya.

Tahap akhir pada model $U$-curve yaitu tahap penyesuaian (adjustment) yaitu para informan telah mencapai pemahaman terkait elemen-elemen kunci dari budaya barunya (Samovar, Porter, McDaniel, \& Roy, 2012), sehingga mereka sudah mendapatkan kenyamanan di lingkungan baru tersebut. Sekalipun masih ada sedikit kecemasan atau hal-hal yang membuat mereka masih belum nyaman, namun sebagian besar gejala gegar budaya sudah mereda.

Tabel. 4 Tahap Penyesuaian dan Jangka Waktu Proses Penyesuaian Diri

Informan Tahap Penyesuaian (Adjustment) Jangka Waktu

\begin{tabular}{llc}
\hline $\begin{array}{l}\text { Alfi Akbar } \\
\text { (Bukittinggi) }\end{array}$ & $\begin{array}{l}\text { Belum menemukan titik nyaman dan kecocokan. Masih } \\
\text { pada transisi antara tahap culture shock dan pemulihan. }\end{array}$ & $\begin{array}{c}\text { 2 tahun bekerja belum } \\
\text { berhasil menyesuaikan } \\
\text { diri }\end{array}$ \\
\hline $\begin{array}{l}\text { Fernando Binsar } \\
\text { N (Balige) }\end{array}$ & $\begin{array}{l}\text { Sudah bisa menikmati hidupnya karena dapat berbaur } \\
\text { dengan baik, dan menjalin ikatan pertemanan yang erat. }\end{array}$ & 1 tahun \\
& Namun belum cocok dengan makanan khasnya. & \\
\hline $\begin{array}{l}\text { Karina Apriyanti } \\
\text { (Nganjuk) }\end{array}$ & $\begin{array}{l}\text { - Merasa sudah nyaman dan cocok dengan lingkungan } \\
\text { kerjanya. } \\
\text { - Menyukai makanan khas Sunda (lalapan) yang } \\
\text { sebelumnya tidak disukai. }\end{array}$ & \\
& - Mampu berinteraksi menggunakan bahasa Sunda. \\
\hline $\begin{array}{l}\text { Titin Agustina } \\
\text { (Temanggung) }\end{array}$ & Merasa lebih nyaman dan terbiasa dengan lingkungan \\
\end{tabular}




\begin{tabular}{lll}
\hline & - Merasa bahagia dan bersikap lebih dewasa. \\
& • Menjalin ikatan personal yang erat. & 3-4 bulan \\
\hline Yohanna S & - Mampu menyesuaikan sikap dalam berinteraksi dengan & \\
(Manado) & karyawan lokal. \\
& - Memahami interaksi dengan berbahasa Sunda. \\
\hline
\end{tabular}

Sumber: olah data pribadi (2019)

Waktu yang dibutuhkan para informan cukup beragam untuk berhasil mencapai tahap penyesuaian (adjustment). Titin, Fernando, dan Karina membutuhkan waktu satu tahun hingga bisa menyesuaikan diri. Proses adaptasi yang paling cepat dialami oleh Yohanna yaitu selama 3-4 bulan. Perbedaan jangka waktu tersebut dapat dipengaruhi oleh karakter dan kompetensi komunikasi individu. Dari segi karakter, masing-masing informan menunjukkan karakter yang berbeda. Titin merupakan perempuan pemalu dan memiliki krisis kepercayaan diri saat awal bekerja, Fernando yang cukup terbuka dan memiliki keinginan kuat untuk diterima, Alfi yang cenderung cuek dan tidak begitu memikirkan pandangan orang lain hanya saja ia memutuskan untuk segera kembali ke kampung halamannya karena tidak menemukan kecocokan dan tidak mencapai tahap penyesuaian.

Pada tahap penyesuaian ini, kecemasan dan perasaan negatif yang sebelumnya dirasakan berangsur menghilang dan beralih pada rasa nyaman. Dari hasil upaya penyesuaiannya, beberapa informan kini mampu berbaur dengan baik dan berkomunikasi secara lancar dengan para karyawan lokal, menjalin hubungan interpersonal yang lebih dekat, hingga menyukai makanan khas budaya Sunda yaitu lalapan yang sebelumnya tidak mereka sukai. Beberapa informan juga merasa ada perubahan pada kebiasaan dan cara mereka berbicara dengan logat bahasa Sunda.

Berdasarkan hasil penelitian, bentuk gegar budaya, upaya penyesuaian diri, jangka waktu penyesuaian, hingga hasil upaya penyesuaian pada masing-masing informan menunjukkan bahwa fenomena gegar budaya pada tiap individu bervariasi. Hal tersebut dapat menjelaskan bahwa kompetensi komunikasi antarbudaya antara satu individu dan individu lainnya berbeda-beda. Dalam hal ini, kemampuan berkomunikasi, kemampuan bersosialisasi, karakter individu dan pengalaman dalam lintas budaya sangat berpengaruh terhadap pengalaman gegar budaya yang diterima. Namun, secara keseluruhan berdasarkan model $U$-curve (Lysgaard, 1955) telah merepresentasikan fenomena culture shock yang terjadi pada para informan. Hanya saja transisi dari setiap tahapannya, proses adaptasi, dan jangka waktu setiap individu tidak semuanya sama.

\section{SIMPULAN}

Bentuk gegar budaya yang dialami para informan secara umum dapat dibagi menjadi dua kategori. Pertama, gegar budaya pada perbedaan lingkungan, terdiri dari bahasa, makanan, dan cuaca. Kedua, gegar budaya pada kehidupan sosial yang terdiri dari sikap diskriminatif karena perbedaan suku dan budaya, penilaian negatif oleh informan terhadap karyawan lokal berdasarkan pengalaman pribadi, dan ketidaknyamanan informan atas iklim komunikasi di perusahaan.

Pengalaman gegar budaya berdasarkan model $U$-curve menunjukkan ada empat tahapan yang umumnya dilalui individu. Pada tahap awal yaitu honeymoon, para informan merasa bersemangat dan menaruh ekspektasi yang tinggi terhadap lingkungan barunya. Selanjutnya, yang terjadi pada tahap krisis yaitu muncul kebingungan, keterkejutan, hingga kekecewaan karena ekspektasinya tidak sesuai dengan realita. Kekecewaan tersebut disebabkan ragam perbedaan budaya antara budaya lokal dengan budaya asli para informan. 
Pada tahap pemulihan (recovery), para informan melakukan upaya adaptasi di lingkungan kerja dengan cara berinteraksi secara intens dengan para karyawan lokal, mempelajari bahasa Sunda, memahami karakter dan kebiasaan para karyawan lokal, dan berpartisipasi dalam kegiatan di luar perusahaan. Tahap terakhir yaitu penyesuaian (adjustment) di mana para informan berhasil beradaptasi dan memahami elemen-elemen kunci budaya. Hanya satu informan yang masih berada di transisi antara fase krisis dan pemulihan (recovery). Hasil dari penyesuaian diri tersebut tergantung pada kompetensi komunikasi dan karakter masing-masing informan.

\section{DAFTAR PUSTAKA}

Aldino, K. M. (2020). Gegar Budaya dan Kecemasan: Studi Empiris pada Mahasiswa Bengkulu dan Maluku di Universitas Gunadarma dalam Beradaptasi di Lingkungan Baru. Jurnal Ilmu Komunikasi, 8(2), 88-96.

Bank Indonesia. (2020). Laporan Perekonomian Indonesia 2019. Jakarta: Bank Indonesia. Diambil kembali dari https://www.bi.go.id/id/publikasi/lapor an-

tahunan/perekonomian/Pages/LPI_201 9.aspx

Dayaksini, T. (2012). Psikologi Lintas Budaya. Malang: UMM Press.

Devinta, M., Hidayah, N., \& Hendrastomo, G. (2015). Fenomena Culture Shock (Gegar Budaya) Pada Mahasiswa Perantauan di Yogyakarta. Jurnal Pendidikan Sosiologi, 1-15.

Devito, J. A. (2015). Human Communication: The Basic Course. New York: Pearson. Fadillah, P. B. (2020). Adaptasi Antarbudaya Mahasiswa Asal Aceh di Universitas Pertamina dalam Menghadapi Gegar Budaya. Jakarta: Universitas Pertamina.

Hendariningrum, R. (2018). Budaya dan Komunikasi Kesehatan: Studi Pandangan Kesehatan Pada Masyarakat
Sunda dalam Tradisi Makan Lalapan. Jurnal Lugas, 02(1), 13-19.

Karmilah, \& Sobarudin. (2019). Konsep Dan Dinamika Komunikasi Antarbudaya. Jurnal Dakwah dan Komunikasi, 4(1), 42-55.

Kemenperin. (2019, Juli 9). Pertumbuhan Melonjak, Inudstri Manufaktur Berkontribusi Hingga 20 Persen. Diambil kembali dari Kemenprin.go.id: https://www.kemenperin.go.id/artikel/1 9213/Pertumbuhan-Melonjak,-IndustriManufaktur-Berkontribusi-Hingga-20-

Persen\#: :text=Pertumbuhan $\% 20$ Melo njak\%2C\%20Industri\%20Manufaktur $\% 20$ Berkontribusi\%20Hingga\%2020\% 20Persen,-

Sabtu\%2C\%2012\%20Mei\&text $=\%$ E2 $\% 80 \% 9$ CPertumb

Lysgaard, S. (1955). Adjustment in a Foreign Society: Norwegian Fulbright Grantees Visiting the United States. International Social Science Bulletin, 45-51.

Mulyana, D. (2018). Metodologi Penelitian Kualitatif: Paradigma Baru Ilmu Komunikasi dan Ilmu Sosial Lainnya. Bandung: Remaja Rosdakarya.

Nunez, C., Mahdi, R. N., \& Popma, L. (2017). Intercultural Sensitivity: From Denial to Intercultural Competence. Netherland: Royal Van Gorcum BV.

Oberg, K. (1960). Cultural Shock: Adjustment to New Cultural Environments. Sage Publications, 177-182.

Rahardjo, T., Dwiningtyas, H., \& Pradekso, T. (2018). Komunikasi Penyesuaian Diri Kembali Pekerja Migran Perempuan yang Kembali ke Daerah Asal. Aspikom, 3(5), 817-832.

Rahman, A. A., Sarbini, Tarsono, Fitriah, E. A., \& Mulyana, A. (2018). Studi Eksploratif Mengenai Karakteristik dan Faktor Pembentuk Identitas Etnis Sunda. Jurnal Psikologi Islam dan Budaya, 1(1), 1-8.

Rakhmat, J., \& Mulyana, D. (2006). Komunikasi Antarbudaya: Panduan Berkomunikasi dengan Orang-Orang 
Berbeda Budaya. Bandung: PT Remaja Rosda Karya.

Rustandi, Y., \& Anggradinata, L. P. (2019). Representasi Etos Kerja Orang Sunda dalam Ungkapan dan Folklor Sunda. Jurnal Salaka, 1(1), 33-40.

Samovar, L. A., Porter, R. E., McDaniel, E. R., \& Roy, C. S. (2012). Communication Between Cultures. Boston: Monica Eckman.

Setyaningrum, P. M. (2019, November 23). Ekonomi Digital Berkembang Pesat, Permintaan Talenta Digital dan Gaji Meningkat di 2020. Diambil kembali dari

Wartaekonomi.co.id: https://m.wartaekonomi.co.id/berita258 039/ekonomi-digital-berkembangpesat-permintaan-talenta-digital-dangaji-meningkat-di-2020

Sihabudin, A. (2013). Komunikasi Antarbudaya Satu Perspektif Multidimensi. Jakarta: PT. Bumi Aksara.

Suyandari, N. (2012). Culture Shock Communication Mahasiswa Perantauan di Madura. Madura: Universita Trunojoyo.

Utami, L. S. (2015). Teori-Teori Adaptasi Antarbudaya. Jurnal Komunikasi, 7(2), 180-197. 